\title{
A Q-Methodological Analysis of School Principals' Decision-Making Strategies during the Change Process at Schools
}

Mehmet Semin Summak ${ }^{1}$ And Mahmut Kalman ${ }^{\star 2}$

$\approx$ The purpose of the research was to explore the decision-making strategies that school principals employ while dealing with the challenges faced during the change process at schools. The study was conducted in two cities located in Central and Southeast Turkey, with a sample comprising 29 primary, middle and secondary school principals, selected via a purposive sampling technique. Q methodology, a qualitative-dominant mixed methods research design, was used in the study. The researchers developed and used a concourse of 24 specific items that target school principals' decision-making strategies about change-related challenges in schools by taking a perception-driven decision-making model as the theoretical framework. The statistical software PQMethod was used for data analysis. The findings revealed that school principals shared similar views via the item configurations provided regarding decision-making during times of change, and had a similar profile in terms of decisionmaking and related strategies. The behavioural decision style was found to be the preferred style. The principals had a profile featuring a high focus on people and low cognitive complexity. The dominant beliefs driving their decision-making strategies seemed to incorporate comprehensive evaluation of the current situation, ethical concerns and organisational values, assessment of technical details, and thorough data collection. Some implications are drawn for researchers and practitioners.

Keywords: school principals, organisational change, decision-making strategies, decision-making profile, Q methodology

1 Faculty of Education, Gaziantep University, Turkey.

$2{ }^{\star}$ Corresponding Author. Department for Primary Education, Faculty of Education, Gaziantep University, Turkey; mahmutkalman@gmail.com. 


\section{Q-metodološka analiza strategij odločanja ravnateljev med procesom uvajanja šolskih sprememb}

Mehmet Semih Summak in Mahmut Kalman

$\propto$ Namen raziskave je bil preučiti strategije odločanja, ki jih uporabljajo ravnatelji pri spoprijemanju z izzivi v procesu uvajanja šolskih sprememb. V raziskavi, ki je bila izvedena $\mathrm{v}$ dveh mestih $\mathrm{v}$ osrednji in jugovzhodni Turčiji, je sodelovalo 29 ravnateljev osnovnih in srednjih šol, izbranih s tehniko namenskega vzorčenja. $\mathrm{V}$ raziskavi smo uporabili metodologijo Q, tj. dominantno kvalitativno raziskavo mešanih metod. Raziskovalci so razvili in uporabili nabor 24 specifičnih elementov, ki so se osredinjali na strategije odločanja ravnateljev glede izzivov, povezanih s šolskimi spremembami, pri čemer so kot teoretični okvir uporabili model odločanja, ki temelji na zaznavi. Za analizo podatkov smo uporabili statistično programsko opremo PQMethod. Na osnovi podane konfiguracije elementov so rezultati pokazali, da so imeli ravnatelji podobne poglede na sprejemanje odločitev v obdobju sprememb ter podoben profil pri sprejemanju odločitev in s tem povezanih strategij. Prevladujoči slog odločanja je bil vedenjski. Osebnostni profil ravnateljev je pokazal močno osredinjenost na ljudi in nizko kognitivno kompleksnost. Videti je, da prevladujoča prepričanja ravnateljev, ki vplivajo na njihove strategije odločanja, obsegajo celovito oceno trenutnega stanja, etične premisleke in organizacijske vrednote, oceno tehničnih podrobnosti in temeljito zbiranje podatkov. Nekateri sklepi v članku so namenjeni raziskovalcem in strokovnim delavcem v vzgoji in izobraževanju.

Ključne besede: ravnatelji, organizacijske spremembe, strategije odločanja, profil odločanja, Q-metodologija 


\section{Introduction}

Decision-making is a significant management process (Lunenburg, 2010a) and stands out as one of the most critical responsibilities of managers (Atsan, 2017; Drucker, 2001). It involves choosing the most reasonable view or alternative from a variety of views and alternatives related to an issue, and making a judgment in order to attain the desired result (Şişman, 2010). Bursalıoğlu (2013) regards decision-making as the heart of management, arguing that it serves as an axis for other management processes. In all organisational settings, including educational organisations, decision-making is an essential management task (Clayton, 1997), as people who hold administrative positions have to make decisions in order to accomplish their daily responsibilities (Khasawneh, Alomari, \& Abu-tineh, 2011). School principals are among the main actors responsible for decision-making in the daily running of schools. However, the way they tend to act with regard to decision-making during organisational change is an issue requiring further investigation. This study therefore attempts to explore school principals' decision-making strategies during organisational change at schools, thus contributing to the existing literature on decision-making and organisational change.

\section{Literature Review}

Decision-making inherently covers a dynamic and complex set of processes (D’Angelo, 2011) often requiring the participation of many stakeholders, not just the manager, and a compendium of various characteristics and strategies. The decision-making process can be characterised as "the process of coping with contradictions and inconsistencies that emerge over time from different sources" (Eranova \& Prashantham, 2016, p. 194). Decision-making styles describe the manner in which people make decisions, react to problems, handle information and interact with others (Boulgarides, 1984). In the educational domain, for example, a decision-making style refers to the method employed by school principals in certain administrative tasks when faced with a situation that necessitates choosing between two or more possible choices or actions in order to arrive at a conclusion (Weiss, 1956). In the literature related to decision-making in schools, one of the most investigated topics is the link between decision-making, on the one hand, and leadership and personality traits, on the other. With regard to leadership and personality traits, Mason (2016) found that, compared to other variables, leadership style had the most impact on principals' decision-making, a result that was confirmed in a study by Hariri, 
Monypenny and Prideaux (2014). Güçlü, Özer, Kurt and Koşar (2015) found that school principals' personality traits and leadership styles had an effect on their decision-making style. Likewise, Ercan and Altunay (2015) found that there was a positive relationship between school principals' personality traits and decision-making styles. With regard to certain other variables, such as experience, Nixon (2017) revealed that seniority in principalship and previous work experience influenced the way principals made decisions. In the Trimmer (2016) study, it was determined that experienced principals are more likely to take risks in decision-making. Finally, in a study by Halama (2017), self-regulation was found to be an important element in decision-making regarding workplace situations. The author determined that high self-regulation increases vigilant thinking and eliminates maladaptive ways, such as procrastination or buck-passing. Taken together, leadership and personality traits, experience, and self-regulation are some of the aspects linked with the decision-making approaches of school principals, as suggested in previous research.

School principals constitute the administrative staff who have to make decisions concerning the running of schools. They do the planning, organising, leading and monitoring required in order for schools to function (Lunenburg, 2010b), and must deal with a range of diverse situations (Hoy \& Tarter, 2010). While undertaking these tasks and managerial responsibilities, and when dealing with situations, school principals need to make decisions by considering both internal and external factors. At this point, the system within which school principals have to make decisions seems to be the determining factor regarding decision-making. In Turkey, public school principals are entrenched in behavioural patterns and responsibilities structured by governmentalities (Kalman \& Arslan, 2016); therefore, the decision-making process may be affected by a variety of factors, most of which are elements of the centralised system-wide structure, such as the regulations of the Ministry of National Education (MoNE). Sezer (2016) evinced that Turkish school principals are affected by certain internal and external factors in the decision-making process. Among the internal factors are teachers' views and suggestions, vice-principals' views and suggestions, and the instructional goals of the school. The external factors are reported to be laws and regulations, the views and suggestions of school-parent associations, the general education policy of the country, and the demands of the top management of the MoNE. The Sezer (2016) study was framed according to school principals' perceptions, and the participants in the study did not therefore count themselves among the influencing factors. In a different study by Güçlü et al. (2015), however, teachers argued that school principals and regulations affect the decision-making process. Bakioğlu 
and Demiral (2013) consistently found that school principals examined regulations when beset with uncertainty while making decisions. Furthermore, they needed support from their vice-principals and experienced managers of other schools, as well as from teachers and school counsellors in their own schools. The evidence provided in the Shakeel and DeAngelis (2017) study consistently demonstrates that the influence of private school principals on school-level activities through decision-making is greater than that of public school principals. All of these research results support the findings of Bursalığlu (2013), who argued that the most powerful factor affecting the decision-making process, taking into account both internal and external factors, is the degree of centralisation. Another significant issue affecting decision-making is organisational culture. The type of culture organisations nurture may affect the way decisions are made (Al-Yahya, 2008; Basi, 1998). Keeping this in mind, the present study attempts to reveal how Turkish school principals make decisions while dealing with problems arising in the organisational change process. The study is significant in that it aims to provide exploratory information with regard to school principals' decision-making strategies during the change process, with the hope of filling the void in the related literature by evincing the strategies employed by school principals in times of change. It is widely accepted that change has become an integral part of organisational policy-making due to its far-reaching effects for the survival, development and renewal of an organisation (Fullan, 2007; James, 2011; Lewis, 2011). Change in organisations may lead to major alterations in structures, strategies and culture, as well as minor modifications such as rules and procedures (Smollan, 2017), usually accompanied by a cascade of uncertainties, problems and complexities. In an atmosphere of high turbulence and turmoil, school principals have to make decisions, which confronts them with two difficult managerial tasks: decision-making and change management. The present study therefore attempts to gain insight into the decision-making strategies of school principals during the change process.

\section{Purpose of the Study}

The present study attempts to explore decision-making strategies used by school principals while dealing with the challenges faced during the change process at schools. To this end, the research question that guided the present study was: What do school principals pay more attention to while making decisions during the change process at schools?

The research had the following objectives:

- To provide first-hand descriptions of the decision-making styles of a 
group of school principals, as perceived by them during times of organisational change.

- To present Q methodology-induced data (with a mixture of qualitative and quantitative research traditions) in order to gain a deeper insight into the decision-making styles employed by school principals in two different cities with varying cultural and contextual aspects.

- $\quad$ To expose the emerging value-laden aspects (if any) of the decisions made by school principals on turbulent ground with some ambiguity (at times of organisational change).

\section{Method}

Q methodology was employed in the present study in order to gain an insight into school principals' decision-making strategies. Q methodology has been recognised as a mixed research approach (Newman \& Ramlo, 2010; Ramlo \& Newman, 2011), as qualiquantology (Stenner, 2011), and more recently as a qualitative-dominant mixed method research (Ramlo, 2016a) that examines human subjectivity (Brown, 1996; Ramlo, 2005, 2016c), that is, "the communication of a personal point of view" (McKeown \& Thomas, 2013, p. 2). This methodology helps us to understand the diversity of perspectives (Zabala, 2014) and compare various typologies regarding individuals' behaviour patterns (Yang \& Bliss, 2014).

In the present study, the research question was probed using $\mathrm{Q}$ methodology because it involves determining various views within a group about a specific topic and the co-construction of meaning depending on views (Hutson \& Montgomery, 2011; Newman \& Ramlo, 2010). According to Ramlo (2016a), Q is a methodology comprising a technique, a method and a philosophical framework, rather than being a technique of measurement or a method. It covers the data collection procedure, the analytic process, and the conceptual and philosophical framework (Ramlo, 2016b). Two open-ended questions were provided below the concourse to reveal why the principals preferred the "most like" and "most unlike" statements. This allowed them to explain the underpinnings of their preferences of decision-making strategies. The answers to these questions were presented through qualitative descriptions.

\section{Participants}

At the beginning of the study, a total of 31 school principals working at primary, middle and secondary schools participated in the study. The 
participants (the P-set) were chosen according to pragmatic considerations (McKeown \& Thomas, 2013) concerning their potential to have varying points of view about the topic under investigation (Paige, 2014). The principals were recruited from two cities in Central $(N=19)$ and Southeast Turkey $(N=12)$. However, only 29 of the Q-sorts were usable: two forms were not filled out correctly and were therefore removed from the dataset. The demographic characteristics of the participants are presented in Table 1.

Table 1

Demographic characteristics of the participants

\begin{tabular}{llcc}
\hline Demographics & & N & $\%$ \\
\hline \multirow{2}{*}{ Gender } & Male & 25 & 86.1 \\
& Female & 4 & 13.9 \\
\hline \multirow{2}{*}{ Age } & 25-35 years & 8 & 27.5 \\
& 36-45 years & 17 & 58.6 \\
& 46-55 years & 4 & 13.9 \\
Seniority in & 1-5 years & 14 & 48.3 \\
& 6-10 years & 9 & 31 \\
& 11 years or more & 6 & 20.7 \\
\hline \multirow{2}{*}{ School type } & Primary & 10 & 34.5 \\
& Middle & 6 & 20.7 \\
& Secondary & 13 & 44.8 \\
\hline
\end{tabular}

As Table 1 shows, the majority of the participants were male $(N=25)$. More than half of them $(N=17)$ were $36-45$ years of age, and nearly half of them $(N=14)$ had $1-5$ years of experience in principalship. Most of them were employed at primary $(N=10)$ and secondary $(N=13)$ schools.

\section{Data Collection Procedures}

The researchers first drafted a comprehensive collection of statements (Paige, 2014; Ramlo, 2011, 2016a) based on Rowe and Boulgarides's (1983) perception-driven decision-making model. The first concourse of statements included 32 items based on four decision-making styles (analytical, behavioural, conceptual and directive), as suggested in the Rowe and Boulgarides model. Half of the statements were negative and the other half were positive. After forming the first draft of the concourse (the Q sample), the researchers sent it to 
three other researchers in the field of education to check the comprehensibility of the statements and whether there were linguistically overlapping statements. Some statements were re-worded, and eight statements were removed from the concourse after receiving the external researchers' suggestions. The final concourse included 24 statements about the decision-making approaches/strategies of school principals in the change process. The Q sample was presented to the participants to rank-order the statements into a quasi-normal distribution grid on a nine-point scale (i.e., two statements each at $-/+4$, two at $-/+3$, three at $-/+2$, three at $-/+1$, and four at 0 ) from +4 (most like my view) to -4 (most unlike my view). Two open-ended questions were also provided below the $\mathrm{Q}$ sorting grid to reveal the participants' underlying views regarding +4 and -4 statements through their own written explanations or statements. Table 2 shows the final version of the concourse and the numbers assigned to the items on the grid.

Table 2

The Q Sample (Concourse)

\begin{tabular}{ll}
\hline & In the decision-making process: \\
\hline Inalytical & I try to obtain every detail and all technical information related to the problem. (23) \\
Style & I try to find innovative solutions to problems. (8) \\
I prefer to think about the problem superficially. (17) \\
I trust my intuition. (4) \\
The important thing is to produce a solution to the current problem. (21) \\
\hline I believe that social relations in my school are at the heart of decision-making \\
processes. (16) \\
When making a decision, I refrain from making long-term analyses. (3) \\
In any decision-making process, you need to think about how it will affect those on \\
the receiving end. (11) \\
In any decision-making process, I try to carefully review/consider everything related \\
to the problem. (18) \\
The decision-making process can be a selfish one. (7) \\
When making a decision, if necessary, I can disregard social relations in my school. (2) \\
\hline Decision-making is a process that involves risk-taking. (13) \\
When making decisions, I consider ethical and value-based issues carefully. (24) \\
I believe in the necessity of sharing power and authority in the decision-making \\
process. (15) \\
In the decision-making process, I try to be careful not to cause negative conse- \\
quences. (9) \\
Rationality/logic is the most important thing guiding me in decision-making. (20) \\
I feel the need to control everything while making a decision. (1)
\end{tabular}


As shown in Table 2, the final concourse included 24 statements representing four different aspects of the decision-making model used in the study. Figure 1 shows the quasi-normal distribution grid that was presented to the participants to rank-order the given statements, each of which was numbered randomly, based on their own preferences. Each statement was written on a small card with its assigned number in order to make it easy for the participants to sort the statements into the corresponding box on the grid (Crosby, 2015). The quasi-normal distribution grid used in the research is provided in Figure 1.

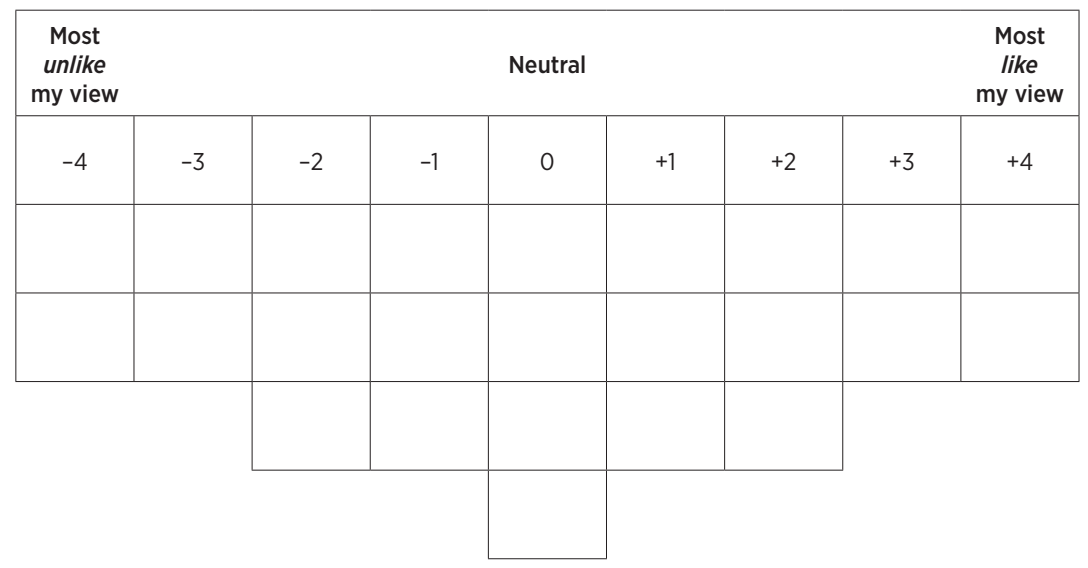

Figure 1. The quasi-normal distribution grid.

Before conducting the research, the participants were given information and instructions on how to use the statements and the grid. Each participant was asked to sort, rank and order the statements in the Q sample using the grid provided in Figure 1. The ranking/sorting/ordering process lasted about 15 minutes for each participant. As the selected principals participated in the study on a voluntary basis, the data were collected over a period of one month.

After the data were gathered, the Q sorts of the participants (the ranking of the statements) were analysed using PQMethod 2.35 software (Schmolck, 2015), which is available for research purposes free of charge. The Q sorts were examined using factor analysis and interpretation to determine whether the participants' views converged or diverged regarding the research topic (Paige, 2014). The use of factor analysis enabled the researchers to determine how the participants shared similar to divergent points of view (Paige, 2015). The significance level was calculated using the equation $(=2.58 \times(1 \div \sqrt{ }$ no. of items in Q set)), as specified in Demir and Kul's (2011) book on Q methodology and Crosby's (2015) research. It was found to be .526 for the present study. 


\section{Findings}

As a result of the principal component analysis followed by hand rotation, it was seen that the participants' views were grouped into one factor. Following the hand rotation, the participants who were represented by a factor were flagged/selected and indicated with Xs (Newman \& Ramlo, 2010). Only one participant's views diverged from the rest of the principals. A total of 28 participants (96.55\%) were found to share similar views about their decisionmaking strategies during the change process at schools. The principals' answers to the open-ended questions were also used as qualitative evidence in relevant contexts to reveal the rationale and the cognitive processes (strategies) employed in decision-making. The factor loadings concerning the items and factors are presented in Table 3.

Table 3

Factor Loadings

\begin{tabular}{|c|c|c|c|}
\hline Participant & Factor 1 & Participant & Factor 1 \\
\hline 1 & $.8511 X$ & 16 & $.5263 X$ \\
\hline 2 & $.7040 x$ & 17 & $.6796 \mathrm{X}$ \\
\hline 3 & $.6845 X$ & 18 & $.5992 X$ \\
\hline 4 & $.7467 X$ & 19 & $.5956 X$ \\
\hline 5 & $.7847 X$ & 20 & $.6908 \mathrm{X}$ \\
\hline 6 & $.7142 X$ & 21 & $.6909 x$ \\
\hline 7 & $.8731 \mathrm{X}$ & 22 & $.8344 X$ \\
\hline 8 & $.7571 X$ & 23 & $.6642 X$ \\
\hline 9 & $.6413 X$ & 24 & $.5789 x$ \\
\hline 10 & $.6679 x$ & 25 & $.4654^{*}$ \\
\hline 11 & $.8895 X$ & 26 & $.6943 X$ \\
\hline 12 & $.6432 x$ & 27 & $.8373 x$ \\
\hline 13 & $.6775 X$ & 28 & $.6511 X$ \\
\hline 14 & $.7450 x$ & 29 & $.6033 x$ \\
\hline 15 & $.6931 X$ & & \\
\hline Total participants & & 29 principals & \\
\hline $\begin{array}{l}\text { Explanation } \\
\text { variance }\end{array}$ & & $50 \%$ & \\
\hline Eigenvalue & & 14.3971 & \\
\hline
\end{tabular}

Note. No significant loading on any factors. 
Table 3 indicates the factor loadings that were equal or higher than the significance level, which was determined to be .526 in this study. A total of 28 participants significantly loaded on Factor 1 . The factor loading belonging to the $25^{\text {th }}$ participant was not significant. Factor 1 had an Eigenvalue of 14.3971 and explained $50 \%$ of the total variance. Table 4 indicates $Z$ scores regarding the statements and Z-score rankings of the statements. The statements were ranked based on the points of view of 28 principals.

Table 4

$Z$ scores regarding the statements and the ranking significance of the statements

\begin{tabular}{|c|c|c|}
\hline \multirow[b]{2}{*}{ Statement } & \multicolumn{2}{|c|}{ Factor 1} \\
\hline & Z & Rank \\
\hline $\begin{array}{l}24 \text { When making decisions, I consider ethical and value-based issues care- } \\
\text { fully. (CON) }\end{array}$ & 1.414 & 1 \\
\hline $\begin{array}{l}18 \text { In any decision-making process, I try to carefully review/consider every- } \\
\text { thing related to the problem. (BEH) }\end{array}$ & 1.384 & 2 \\
\hline $\begin{array}{l}14 \text { To me, every decision should be based on extensive/careful evaluations. } \\
\text { (DIR) }\end{array}$ & 1.327 & 3 \\
\hline 8 I try to find innovative solutions to problems. (ANAL) & 1.182 & 4 \\
\hline $\begin{array}{l}23 \text { I try to obtain every detail and all technical information related to the } \\
\text { problem. (ANAL) }\end{array}$ & 1.172 & 5 \\
\hline $\begin{array}{l}21 \text { The important thing is to produce a solution to the current problem. } \\
\text { (ANAL) }\end{array}$ & .889 & 6 \\
\hline $\begin{array}{l}6 \text { I try to produce as many different alternatives as possible when making a } \\
\text { decision. (DIR) }\end{array}$ & .861 & 7 \\
\hline 13 Decision-making is a process that involves risk-taking. (CON) & .546 & 8 \\
\hline $\begin{array}{l}9 \text { In the decision-making process, I try to be careful not to cause negative } \\
\text { consequences. (CON) }\end{array}$ & .383 & 9 \\
\hline $\begin{array}{l}11 \text { In any decision-making process, one needs to think about how it will affect } \\
\text { those on the receiving end. (BEH) }\end{array}$ & .367 & 10 \\
\hline $\begin{array}{l}20 \text { Rationality/logic is the most important thing guiding me in decision- } \\
\text { making. (CON) }\end{array}$ & .355 & 11 \\
\hline 12 I would like to make decisions based on the data available to me. (ANAL) & .181 & 12 \\
\hline $\begin{array}{l}22 \text { I tend to make a choice from among the options in the decision-making } \\
\text { process. (DIR) }\end{array}$ & -.168 & 13 \\
\hline $\begin{array}{l}15 \text { I believe in the necessity of sharing power and authority in the decision- } \\
\text { making process. (CON) }\end{array}$ & -.243 & 14 \\
\hline 4 I trust my intuition in the decision-making process. (ANAL) & -.426 & 15 \\
\hline 5 I feel time pressure in the decision-making process. (DIR) & -.487 & 16 \\
\hline 1 I feel the need to control everything while making a decision. (CON) & -.502 & 17 \\
\hline $\begin{array}{l}16 \text { I believe that social relations in my school are at the heart of decision- } \\
\text { making processes. (BEH) }\end{array}$ & -.587 & 18 \\
\hline
\end{tabular}




\begin{tabular}{lcc}
\hline \multirow{2}{*}{ Statement } & Factor & \multicolumn{2}{c}{ Factor 1 } \\
\cline { 3 - 3 } $\begin{array}{l}19 \text { I expect to see/feel everyone's respect for the decision I have made. } \\
\text { (DIR) }\end{array}$ & -.631 & Rank \\
\hline $\begin{array}{l}\text { Z When making a decision, I refrain from making long-term analyses. } \\
\text { (BEH) }\end{array}$ & -.882 & 20 \\
\hline $\begin{array}{l}2 \text { When making a decision, if necessary, I can disregard social relations in } \\
\text { my school. (BEH) }\end{array}$ & -1.039 & 21 \\
\hline $\begin{array}{l}10 \text { I do not care much about whether other people I work with approve of } \\
\text { my decisions or not. (DIR) }\end{array}$ & -1.307 & 22 \\
\hline $\begin{array}{l}17 \text { I prefer to think about the problem superficially. (ANAL) } \\
7 \text { The decision-making process can be a selfish one. (BEH) }\end{array}$ & -1.754 & 23 \\
\hline
\end{tabular}

Table 4 demonstrates the $\mathrm{Z}$ scores belonging to each statement after the analytic process. It was found that 12 statements had positive values and 12 had negative values. Positive values indicated that the school principals agreed with the statements regarding the aspects considered during the decision-making process, whereas negative values referred to the statements that the school principals disagreed with while making decisions during the change process. When the top six "most like my view" statements are examined, it can be seen that the school principals paid attention to considering ethical and value-based issues carefully in the decision-making process. The statement "When making decisions, I consider ethical and value-based issues carefully" had the highest $\mathrm{Z}$ score $(Z=1.414)$, implying that the participating principals seemed to perceive themselves as value-laden administrators when engaged in decision-making at times of organisational change.

The statement with the second highest $\mathrm{Z}$ score was related to the careful delineation of every detail related to the challenges faced in the decision-making process; "In any decision-making process, I try to carefully review/consider everything related to the problem". Making careful evaluations, finding innovative solutions to problems, endeavouring to access all technical information and details related to the problems, and viewing the solution of the current problems as pivotal were among the issues that the school principals paid more attention to prior to making decisions about the challenges faced during the change process at schools. $\mathrm{P}_{3}$ explained his views as follows: "It is of high importance to be ethical in decisions, to get them internalised and to be well informed about the problems." Another principal commented: "Being mindful and thoughtful is important in decisions. Logical decisions should pass through the ethical values filter..." ( $\left.\mathrm{P}_{27}\right)$. $\mathrm{P}_{9}$ noted that: "The most important thing in the decision-making process is to find a solution to the problem. This must be done by complying with values and ethics..." Consistent with $\mathrm{P}_{3}, \mathrm{P}_{27}$ and $\mathrm{P}_{9}$, participant 
P2o believed that: "If a decision is to be made, it should first be considered in detail and made in accordance with ethical rules..."

$\mathrm{P}_{4}$ focused on the significance of the decision-making process: "Decision-making is a fine-tuned task and a process that requires attention to details..." $\mathrm{P}_{21}$ had similar views: "Before making a decision, I prioritise analysing everything thoroughly to avoid making mistakes..." $\mathrm{P} 4$ stated that: "Details and technical knowledge are important to me in the decision-making process..." Another principal ( $\mathrm{P}_{26}$ ) noted that: "While giving importance to innovative thinking, having technical knowledge increases the accuracy of my decisions..." In parallel to $\mathrm{P}_{21}, \mathrm{P}_{4}$ and $\mathrm{P}_{26}$, participant $\mathrm{P} 8$ argued that: "Decisions must be made without rushing and by examining every detail..."

As can be understood from the principals' views, ethicalness, values, collecting detailed and technical information, and making careful evaluations were the most highlighted and prioritised factors in decision-making. Hence, either adhering to these principles as an ideal intention or applying them on the ground shows that principals are bound to take values and ethical issues seriously in decision-making processes. Their concerns regarding the issue of obtaining detailed information and making comprehensive evaluations may indicate that the principals were keen to make determined, long-term and sound decisions rather than quick-fix and unsustainable decisions that could exacerbate the existing situations and problems.

The statements that the school principals rejected or disagreed with were seen to have negative $\mathrm{Z}$ scores. A total of 12 statements were rejected by the school principals. The top six "unlike my view" statements were related to self-interest (selfishness), a superficial examination of problems, others' views (i.e., respect for or approval) of the decisions made, refraining from long-term analyses, and the role of social relations in the decision-making process. The statement with the highest negative $\mathrm{Z}$ score $(\mathrm{z}=-2.034)$ was; "The decisionmaking process can be a selfish one". This statement was conceived as a negative strategy or approach related to the behavioural approach in decision-making. P1 opined that: "Selfishness affects the functioning of the institution negatively. Social relations at school can never be underestimated..." Another respondent pointed out that: "Monolithic decisions do not assure efficiency..." ( $\left.\mathrm{P}_{2}\right)$, while $\mathrm{P}_{1} 8$ specified the role of consulting others: "Consultation is needed instead of selfishness in the decision-making process..."

The statement with the second highest $\mathrm{Z}$ value was related to the superficial examination of the problems faced. The principals disagreed with this statement, as they may believe that the challenges faced during change require careful delineation and consideration in schools. P11 focused on the negative 
impact of selfish and superficial thinking: "Superficial thinking reduces the quality of judgment. Selfish thinking gives rise to the possibility that the decision may cause new problems in the future..." $\mathrm{P}_{27}$ shared a similar view: "A long thinking period and collaboration should precede decisions..."

Nearly all of the principals had similar views on the negative impacts of selfishness in decision-making during the change process at schools. Obtaining other colleagues' approval regarding decisions was also considered to be significant. It can be suggested that the school principals regarded social relations in schools to be critical in decision-making in the change process. They believed that a superficial or selfish approach may lead to inefficiency, future problems, and dysfunction in the organisation. Some of them delineated their views on the importance of participatory or collaborative decision-making as follows:

"The opinions of the people I work with are important to me; no decisions should disrupt our social relations..." (P8)

"When making decisions, my teammates are supposed to agree with me. I have to make a decision that they will approve of and accept..." (P19)

"It cannot be expected that everyone will respect the decisions made. The people I usually work with are important in the decision-making process..." ( $\left.\mathrm{P}_{23}\right)$

However, three of the principals had divergent views on social relations in decision-making at times of change: "School interests are more important than my social relations with people..." ( $\mathrm{P}_{26} 6$. "If I believe that I have made the right decisions, I do not give much credit to the approval of others..." (P12). "When social relations are placed at the heart of the solution process, instead of relying on available data, decisions made under the heavy burden of emotions will be fast but subjective anyway..." $\left(\mathrm{P}_{7}\right)$.

A Z-score analysis regarding the data collected from the participants displayed the profiles regarding decision-making more clearly. Table 5 shows the four dimensions and their average $Z$ values.

Average $Z$ values were calculated using the following formula, employed by Yildirım (2017):

$Z_{\text {means }}=(Z$ value of each positive statement for each dimension (the sum of 3 positive statements for each dimension) - $Z$ value of each negative statement for each dimension (the sum of 3 negative statements for each dimension)) / 6 
Table 5

Average $Z$ values regarding decision-making dimensions

\begin{tabular}{lccc}
\hline Dimension & $Z_{\text {means }}$ of positive statements & $Z_{\text {means }}$ of negative statements & $X$ \\
\hline Behavioural & 1.164 & -3.955 & .853 \\
Analytical & 2.535 & -1.291 & .638 \\
Directive & .528 & -.933 & .243 \\
Conceptual & 1.554 & .399 & .192 \\
\hline
\end{tabular}

When the school principals' decision-making strategies are examined in the light of average $Z$ values, it can be seen that the most preferred dimensions are behavioural $(X z=.853)$, analytical $(X z=.638)$, directive $(X z=.243)$ and conceptual $(X z=.192)$. Considering the two most preferred dimensions (i.e., behavioural and analytical), it can be asserted that there is a strong focus on social interactions and on the feelings and thoughts of school staff, and that the principals had a high tolerance for ambiguity and attempted to use abundant information when making decisions during the change process. The $Z$ means of these two dimensions were higher than those of directive and conceptual dimensions.

\section{Discussion and Conclusion}

School principals have to make decisions that can affect the school, the instructional programmes, and the students and teachers on a daily basis. These decisions are expected to be good decisions in an environment that requires prompt action (Calabrese \& Zepeda, 1999). At times of organisational change, however, decision-making becomes a more critical issue due to the turbulent nature of change. The present study aimed to reveal how school principals make decisions during the change process and to determine what they care about most: tasks, people or both. The factor analysis indicated that the school principals' decision-making strategies were grouped into one factor, which means that they shared similar decision-making strategies when dealing with the challenges faced during the change process at schools. Based on the findings, it can be suggested that the school principals had a similar profile and general characteristics with regard to decision-making and the strategies used in the decision-making process. It was concluded that the school principals reached a consensus regarding the issues to be considered in the change process. They believed that ethical and value-based issues are significant when making decisions during the change process. In this respect, the principals seemed to 
employ behavioural style-driven decision-making due to the dominant motives arising from context and culture-bounded aspects, such as, arguably, a compelling need for "being socially acceptable and bureaucratically fit". This finding is in accordance with Kasprzhak and Bysik's (2015) study, which found "contextual factors" to be the driving force behind Russian school principals' decision-making processes.

The issues on which the school principals shared similar views were: thinking of or reviewing every detail related to the problems faced, making extensive and careful evaluations, finding innovative solutions to problems, and appealing to thorough data collection. These aspects were supported with the principals' verbal explanations. The points that the school principals rejected or were against were found to be: considering decision-making as a selfish process, handling problems superficially, expecting everyone's respect for the decisions made, refraining from long-term analyses, overlooking social relations in school, and not caring for others' approval of the decisions made. This inclination parallels collective culture theory (Hofstede, Hofstede, \& Minkov, 2010) in which individualistic traits are considered to be socially unfit and somewhat selfish. The influence of managers' national culture on their decision-making styles is also revealed by Podrug (2011) and Yang (2016). A steep hierarchy and a bulky bureaucracy are the dominant/descriptive features of the Turkish education system at all levels of operation. The participating principals' orientation towards carrying out extensive and careful evaluations and appealing to thorough data collection processes may be partly related to these political factors and their adherence to making correct decisions. In fact, the reason for participants' adhering to a "behavioural" style could be explained by politicalinfluence orientation and environmental factors.

Decision-making behaviour is mainly affected by contextual factors such as the level of uncertainty, ever-changing dynamic environments, and competing goals and values (Alenjung \& Persson, 2005). Naturally, decisions made at times of organisational change require special attention, as the environment can be rather turbulent and is characterised by uncertainty. A close examination of the findings suggests that the decision-making style of Turkish principals is partly consistent with that of other international counterparts. For instance, Bayburin, Bycik, Filinov, Isaeva and Kasprzhak (2015) report that some Russian school principals, albeit a minority in the sample, used a conceptual style and became good candidates of reform agents. However, the conceptual style was the least preferred decision-making style in the present study. According to Rowe and Boulgarides (1983), individuals may have one or more dominant styles with one or more substitute styles. Although a behavioural 
decision-making style was the most preferred style, it can be asserted that Turkish school principals use other styles when needed. The second most preferred style (i.e., analytical) could imply that Turkish school principals have a high tolerance for ambiguity in terms of decision-making, which is worthy of further consideration during the change process. Jordanian school principals, on the other hand, mainly use a directive decision-making style (Al-Omari, 2013), while Indian managers were observed to tend towards an analytical style (Misra \& Srivastava, 2012). Based on the average $Z$ values, it can be concluded that Turkish school principals, in this case, favoured people-oriented decisions involving low cognitive complexity. A broader categorisation of the analysis of the top six statements indicates that ethical concerns, organisational values, conducting extensive evaluations prior to decisions, adherence to data-driven decision-making, and innovative problem-solving are the strategies that the school principals agreed upon.

Based on the findings of the research, it can be suggested that, in times of change, principals tend to make decisions taking humanitarian and social aspects into consideration more than technical aspects. Considering humanitarian aspects such as human relations may help the change process to be more value-laden. Accordingly, taking the technical aspects into consideration may both help the change succeed and serve as a catalyst for running the change process smoothly. The results of this study are somewhat consistent with those of Schechter and Shaked (2017), who found that school principals tended to care about teachers' attitudes and abilities, and to take into consideration the characteristics and circumstances of their schools, while also employing their practical wisdom when necessary during educational reform initiatives. Decision-making has the potential to influence an organisation's performance and reputation, as well as its members' welfare and security (George \& Dane, 2016); therefore, considering both humanitarian and technical aspects carefully may benefit both the organisation and its members.

Drawing on the results of the study, we propose that, rather than implementing socially approvable and bureaucratically fit decisions, principals must think about making and implementing decisions promoting and institutionalising change that address the needs of the organisation during the change process, in terms of both tasks and people; this can help staff to achieve better results in the long run. Since the operational conditions of schools and principals in turbulent times (i.e., during organisational change) differ markedly across different cultures, principals often need to adapt context-relevant decisions and ponder contingent situations such as change during the process of decision-making. 
Inter alia, the present study is significant in that it contributes to the existing knowledge base by providing an insight into the profile of school principals' decision-making strategies during the change process. Further research should be conducted with larger samples using different methods and techniques in order to gain more fine-grained evidence regarding school principals' decision-making profiles at times of change in schools. New evidence regarding their decision-making profiles may help enhance the quality of decisions made during organisational change initiatives and encourage the consideration of significant variables while making decisions.

\section{Limitations}

Although the Q-methodology was employed, the analysed data were collected through participants' verbal and written explanations; no direct observations were made by the researchers at the time of the actual decisionmaking practices of the principals. This may be one of the limitations in the study, as the participants' explanations were assumed to be sincere and based on realities. The findings of the study should therefore be considered with this limitation in mind.

\section{Acknowledgement}

An earlier version of this research was partly presented at "14th International JTEFS/BBCC Conference on Sustainable Development, Culture, and Education: Innovations and Challenges of Teacher Education for Sustainable Development" held between 12-14 May, 2016 in Konya, Turkey.

\section{References}

Alenjung, B., \& Persson, A. (2005). Decision-making from the decision-maker's perspective: A framework for analysing decision situations. In Proceedings of the 4 th International Conference on Business Informatics Research (pp. 13-22). Sweden.

Al-Omari, A. A. (2013). The relationship between decision making styles and leadership styles among public school principals. International Education Studies, 6(7), 100-110.

Al-Yahya, K. O. (2008). Power-influence in decision making, competence utilization, and organisational culture in public organizations: The Arab world in comparative perspective. Journal of Public Administration Research and Theory, 19(2), 385-407.

Atsan, N. (2017). Karar vermede çatışma kuramı ve özsaygı ilişkisine yönelik kültürel bir inceleme [A cultural examination of the relationship between decisional self-esteem and conflict theory of 
decision making]. Süleyman Demirel Üniversitesi İktisadi ve İdari Bilimler Fakültesi Dergisi, 22(1), 63-73.

Bakioğlu, A., \& Demiral, S. (2013). Okul yöneticilerinin belirsizlik durumlarını algılama ve karar verme tarzlar1 [Principals' perceptions of ambiguous situations and their decision-making styles in cases of ambiguity]. Eğitim Bilimleri Dergisi, 38, 9-35. doi: 10.15285/EBD.2013385564

Basi, R. S. (1998). Administrative decision making: A contextual analysis. Management Decision, 36(4), 232-240.

Bayburin, R., Bycik, N., Filinov, N., Isaeva, N., \& Kasprzhak, A. (2015). Does conceptual decisionmaking style make school principal an efficient reforms promoter? Basic Research Program, Working Papers Series: Management WP BRP 34/MAN/2015. National Research University Higher School of Economics.

Boulgarides, J. D. (1984). The decision style inventory: O. D. applications. Management Research News, 7(4), 17-20.

Brown, S. R. (1996). Q methodology and qualitative research. Qualitative Health Research, 6(4), $561-567$.

Bursalıoğlu, Z. (2013). Okul yönetiminde yeni yapı ve davranış [New structure and behaviour in school management]. Pegem Akademi.

Calabrese, R. L., \& Zepeda, S. J. (1999). Decision-making assessment: Improving principal performance. International Journal of Educational Management, 13(1), 6-13.

Clayton, M. J. (1997). Delphi: A technique to harness expert opinion for critical decision-making tasks in education. Educational Psychology, 17(4), 373-386.

Crosby, R. (2015). Teachers managing work demands and maintaining a sense of wellbeing: A $Q$ methodology study to investigate the views of primary and secondary school teachers (Unpublished doctoral dissertation). University of Sheffield.

D’Angelo, L. M. (2011). How school organisational structures impact micro-level decision making (Unpublished doctoral dissertation). The George Washington University.

Demir, F., \& Kul, M. (2011). Algı, tutum, karakteristik özellikler, tipoloji, içerik analiz ve araştırmaları için modern bir araştırma yöntemi olarak $\mathrm{Q}$ metodu [Q method as a modern research method for research on perceptions, attitudes, characteristic features, typologies, and content analysis]. Adalet Yayınları.

Drucker, P. F. (2001). The effective decision. In Harvard Business Review on decision making. (pp. 1-20). Harvard Business School Press.

Eranova, M., \& Prashantham, S. (2016). Decision making and paradox: Why study China? European Management Journal, 34(3), 193-201.

Ercan, G., \& Altunay, E. (2015). İlkokul ve ortaokul yöneticilerinin kişilik özellikleri ile karar verme becerileri arasındaki ilişkinin incelenmesi [Investigation of the relationship between the personality characteristics and decision-making skills of primary and secondary school administrators (The case of the İzmir province)]. Ondokuz Mayıs Üniversitesi Eğitim Fakültesi Dergisi, 34(2), 120-143. Fullan, M. (2007). The new meaning of educational change (4th ed.). Teachers College Press. 
George, J. M., \& Dane, E. (2016). Affect, emotion, and decision making. Organizational Behavior and Human Decision Processes, 136, 47-55.

Güçlü, N., Özer, A., Kurt, T., \& Koşar, S. (2015). Liderlik stilleri, karar verme stratejileri ve kişiliğin okullardaki karar sürecine etkilerinin çok düzeyli analizi [Multilevel analysis of the effects of leadership styles, decision making strategies and personality on the decision-making process in schools]. Journal of Human Sciences, 12(2), 1756-1791.

Halama, P. (2017). Self-regulation capacity and decision making of Slovak managers in routine situations and in situations with possible negative outcomes. Studia Psychologica, 59(2), 156-168. Hariri, H., Monypenny, R., \& Prideaux, M. (2014). Leadership styles and decision-making styles in an Indonesian school context. School Leadership \& Management, 34(3), 284-298.

Hofstede, G., Hofstede, G. J., \& Minkov, M. (2010). Cultures and organizations: Software of the mind (3rd ed.). McGraw-Hill.

Hoy, W. K., \& Tarter, C. J. (2010). Swift and smart decision making: Heuristics that work. International Journal of Educational Management, 24(4), 351-358.

Hutson, G., \& Montgomery, D. (2011). Demonstrating the value of extending qualitative research strategies into Q. Operant Subjectivity: The International Journal of Q Methodology, 34(4), 234-246. James, C. (2011). The importance of affective containment for teacher effectiveness and successful educational change. In C. Day \& J. C.-K. Lee (Eds.), New understandings of teacher's work: Emotions and educational change (pp. 119-134). Springer.

Kalman, M., \& Arslan, M. C. (2016). School principals' evaluations of their instructional leadership behaviours: Realities vs. ideals. School Leadership \& Management, 36(5), 508-530.

Kasprzhak A. G., \& Bysik, N. V. (2015). Decision-making styles of Russian school principals. Russian Education and Society, 57(7), 590-613.

Khasawneh, S., Alomari, A., \& Abu-tineh, A. (2011). Decision-making styles of department chairs at public Jordanian universities: A high-expectancy workforce. Tertiary Education and Management, $17(4), 309-318$.

Lewis, L. K. (2011). Organisational change: Creating change through strategic communication. WileyBlackwell.

Lunenburg, F. C. (2010a). The decision making process. National Forum of Educational

Administration \& Supervision Journal, 27(4), 1-12.

Lunenburg, F. C. (2010b). The principal and the school: What do principals do? National Forum of Educational Administration \& Supervision Journal, 27(4), 1-13.

Mason, S. L. (2016). An inquiry into how principals make decisions in secondary schools (Unpublished doctoral dissertation). Indiana State University.

McKeown, B., \& Thomas, D. B. (2013). Q methodology (2nd ed.). Sage.

Misra, S., \& Srivastava, K. B. L. (2012). Decision-making: Path to effectiveness. Human Resource Management Research, 2(4), 46-52.

Newman, I., \& Ramlo, S. (2010). Using Q methodology and Q factor analysis in mixed methods research. In A. Tashakkori \& C. Teddlie (Eds.), Sage handbook of mixed methods in social and 
behavioral research (2nd ed.) (pp. 505-530). Sage.

Nixon, L. A. (2017). School leaders' decision-making process for academic program placement: A phenomenological study. (Unpublished doctoral dissertation). East Tennessee State University.

Paige, J. B. (2014). Making sense of methods and measurement: Q-methodology-part I-philosophical background. Clinical Simulation in Nursing, 10(12), 639-640.

Paige, J. B. (2015). Making sense of methods and measurement: Q-methodology-part IImethodological procedures. Clinical Simulation in Nursing, 11(1), 75-77.

Podrug, N. (2011). Influence of national culture on decision-making style. South East European Journal of Economics and Business, 6(1), 37-44.

Ramlo, S., \& Newman, I. (2011). Reply to Gourlay. Operant Subjectivity: The International Journal of Q Methodology, 34(3), 213-214.

Ramlo, S. (2005). An application of Q methodology: Determining college faculty perspectives and consensus regarding the creation of a school of technology. Journal of Research in Education, 15(1), $52-69$.

Ramlo, S. (2011). Facilitating a faculty learning community: Determining consensus using Q methodology. Mid-Western Educational Researcher, 24(1), 30-38.

Ramlo, S. (2016a). Mixed method lessons learned from 8o years of Q methodology. Journal of Mixed Methods Research, 10(1), 28-45.

Ramlo, S. (2016b). Students' views about potentially offering physics courses online. Journal of Science Education and Technology, 25(3), 489-496.

Ramlo, S. (2016c). Centroid and theoretical rotation: Justification for their use in Q methodology research. Mid-Western Educational Researcher, 28(1), 73-92.

Rowe, A. J., \& Boulgarides, J. D. (1983). Decision styles: A perspective. Leadership \& Organization Development Journal, 4(4), 3-9.

Schechter, C., \& Shaked, H. (2017). Leaving fingerprints: Principals' considerations while implementing education reforms. Journal of Educational Administration, 55(3), 242-260.

Schmolck, P. (2015). PQMethod (Version 2.35) [Computer software]. http://schmolck.userweb.mwn. de/qmethod/downpqwin.htm

Sezer, Ş. (2016). Okul müdürlerinin görev öncelikleri ve karar alma süreçlerini etkileyen faktörlere ilişkin görüşleri [School administrators' opinions on task priorities and the factors affecting their decision-making processes]. İnönü Üniversitesi Eğitim Fakültesi Dergisi, 17(3), 121-137.

Shakeel, M. D., \& DeAngelis, C. A. (2017). Who is more free? A comparison of the decision-making of private and public school principals. Journal of School Choice, 11(3), 442-457.

Şişman, M. (2010). Türk eğitim sistemi ve okul yönetimi [The Turkish education system and school management]. Pegem Akademi.

Smollan, R. K. (2017). Supporting staff through stressful organisational change. Human Resource Development International, 20(4), 282-304.

Stenner, P. (2011). Q methodology as qualiquantology: Comment on Susan Ramlo and Isadore Newman's "Q methodology and its position in the mixed methods continuum". Operant Subjectivity: 
The International Journal of Q Methodology, 34(3), 192-203.

Trimmer, K. (2016). Measurement and modelling: Sequential use of analytical techniques in a study of risk-taking in decision-making by school principals. Teacher Development, 20(3), 398-416. Weiss, H. A. (1956). Decision-making in secondary schools. Phi Delta Kappan, 37(5), 207-210. Yang, G. (2016). A study of cross-cultural decision-making styles: Is cognitive mapping an effective methodology for data analysis? (Unpublished master's thesis). The Open University.

Yang, Y. \& Bliss, L. B. (2014). A Q factor analysis of college undergraduate students' study behaviours. Educational Research and Evaluation, 20(6), 433-453.

Ylldırım, İ. (2017). Students' perceptions about gamification of education: A Q-method analysis. Eğitim ve Bilim, 42(191), 235-246.

Zabala, A. (2014). qmethod: A package to explore human perspectives using Q methodology. The $R$ Journal, 6(2), 163-173.

\section{Biographical note}

Mehmet Semin Summak, PhD, is an associate professor of educational administration at the Faculty of Education, Gaziantep University, Turkey. His research interests include organizational change management and disruptive innovation in education. He is currently engaged in search of building the dynamics of the socio-cultural ecology of academic success.

Mahmut Kalman, $\mathrm{PhD}$, is an assistant professor in the Department for Primary Education, Gaziantep University, Turkey. He received his $\mathrm{PhD}$. degree in educational sciences. His research interests include school leadership, professional development and learning, organizational behavior in education and qualitative research. 